\title{
Life cycle assessment of ceramic façade material and its comparative analysis with three other common façade materials
}

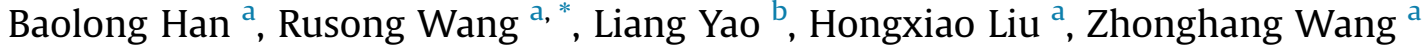 \\ a State Key Laboratory of Urban and Regional Ecology, Research Center for Eco-Environmental Sciences, Chinese Academy of Sciences, Shuangqing Road 18, \\ Haidian District, Beijing 100085, PR China \\ b College of Life Sciences, Anhui Normal University, Wuhu, Anhui Province, PR China
}

\section{A R T I C L E I N F O}

\section{Article history:}

Received 17 October 2014

Received in revised form

2 February 2015

Accepted 9 March 2015

Available online 17 March 2015

\section{Keywords:}

LCA

Façade

Ceramic

Glass

Marble

Aluminum-plastic panel

\begin{abstract}
A B S T R A C T
Ceramic panels are an emerging construction material and have become popular in China due to the regenerative character of the material and its conformation with Chinese culture. In this paper, we conducted a life cycle assessment (from "cradle" to "grave") of decorative ceramic façade panel products from a typical ceramic enterprise in South China. Both the sales aspect and material recycling were considered. Using Ebalance software and its Chinese parameters, we assessed seven environmental impacts of the ceramic panels, including depletion of abiotic resources, photochemical oxidant creation, global warming, acidification, eutrophication, ozone depletion and human toxicity. We also compared the environmental performance of ceramic façade panels with three other traditional curtain wall materials-glass, marble and aluminum plate-using data from the literature. The results from a consideration of the life cycle from "cradle" to "gate" showed that ceramic façade panels had better environmental performance than the others, in general, but was worse than glass on the depletion of abiotic resources performance and was worse than glass and aluminum on the human toxicity performance. Finally, we offer some suggestions for optimizing the life cycle process of ceramic façade panels for better environmental performance and some recommendations for better selection of façade materials.
\end{abstract}

() 2015 Elsevier Ltd. All rights reserved.

\section{Introduction}

Building energy consumption accounts for $30 \%-40 \%$ of the total energy consumption in China. Globally, this percentage is $40 \%$ (Huovila, 2007). The wall body and construction area ratio is approximately $36: 100$, and heat conduction though the wall structure makes up approximately $60 \%-70 \%$ of a building's heat consumption (Incropera, 2011). In addition, the maintenance and cleaning of the curtain wall are the major energy and resource costs of a building (Shameri et al., 2011). Therefore, the selection of an energy-saving façade material is important to green building. Currently, energy efficiency is the major consideration in selecting façade material, whereas the environmental impact over the entire life cycle is limited. Fake green products means high energy

\footnotetext{
* Corresponding author. Tel./fax: +86 1062943807.

E-mail addresses: baronhan@gmail.com (B. Han), wangrs@mail.rcees.ac.cn (R. Wang), dylanyao@126.com (L. Yao), michellewinter@126.com (H. Liu), wondrong@163.com (Z. Wang).
}

efficiency in the usage stage, whereas high energy and resource consumption in the manufacturing stage.

Construction material has become a hot topic in LCA research in recent decades. Glass, aluminum alloy, stone, and ceramic have been analyzed as typical construction materials using the LCA method (Kim, 2011; Nicoletti et al., 2002; Traverso et al., 2010). As an important part of building, a façade's environmental impact has been discussed in a few works. However, most of those works focus on a "green façade" or a "living wall" with less consideration on traditional material façades (Ottelé et al., 2011). Some researches used LCA method on the impact of the green wall, which has not been popular in China until recently (Ottelé et al., 2011). Although attention is decreasing on the LCAs of glass, stone and aluminum alloy, far less LCA research has been performed on ceramic building material than the other three materials. Only one study on ceramic façades was found, which addressed the effects of infrared thermography on the adherence of glaze on ceramic façades (Edis et al., 2014). Comparative study of different material façades is rarely conducted. 
Compared with traditional glass, stone and aluminum façade panels, ceramic façade panels (CFP) did not emerge until 2006, when China produced its first pieces. However, CFP quickly gained ground in the construction market. By the end of 2012, China had built 30 production lines with an annual production capacity of 50 million square meters of CFP. Therefore, it is of practical significance to conduct a life cycle assessment (LCA) on CFP.

Researches on glass façade products were the most common among the four materials due to its wide usage and the wide range of available products. Kim (2011) made a comparative entire life cycle assessment on energy consumption and $\mathrm{CO}_{2}$ emissions of a transparent composite facade system and a glass curtain wall system. In addition to studying glass façades, scholars have also compared the environmental impacts of different glass window materials (Cabeza et al., 2014; Radhi and Sharples, 2013). Citherlet et al. (2000) configured eight different window systems. Weir and Muneer (1998) investigated the embodied energy and $\mathrm{CO}_{2}$ emissions associated with fabricating a window system that consisted of an insulated glass unit, inert gas, timber frame and aluminum components. Research on six impact categories for marble tiles has shown that acidification has the highest relative value, followed by global warming and winter smog (Gazi et al., 2012; Tikul, 2013). Another study on Sicilian marble also showed that tile manufacturing has higher values for embodied energy and environmental performance indicators (Traverso et al., 2010). Although aluminum-plastic plates are a widely used curtain wall material, there have been no independent studies on an aluminum curtain wall, and its environmental performance has been assessed mostly in comparative studies of building materials (Agrawal et al., 2014; Manfredi and Vignali, 2014; Monteiro and Freire, 2012).

A few researchers have conducted research comparing the different façade materials. Taborianski and Prado (2012) compared the entire life cycle $\mathrm{CO}_{2}$ emission of 5 façades and found that structural glazing façades that used colorless glass had the highest $\mathrm{CO}_{2}$ emissions, followed by ceramic brick façades covered with ACM (Advanced Composites Material), structural glazing with reflective glass, and façades built using brick and covered with mortar. Gu et al. (2008) combined LCA and life cycle cost assessment to evaluate the environmental and economic performance of different façade designs and showed that a window-to-wall ratio of 0.45 performed the best; the all-glass curtain wall had the most significant environmental impacts during the construction, operation and replacement stages. A comparative LCA between ceramic tiles and marble tiles as flooring materials showed, in particular, the relevance of the energy consumption in both systems but showed a better environmental profile for the marble tile. The raw materials for glaze manufacturing is responsible for the relevant arsenic emissions during the firing process in the ceramic system (Nicoletti et al., 2002).

Currently, there is no entire life cycle analysis research data available for CFP products. Only "cradle to gate" life cycle analysis research on the glazed thin ceramic tile used in flooring is available (Nicoletti et al., 2002). The thin ceramic tile is used in interior decoration with a production process of pressure molding, but CFP is used in façade decoration with a production process of extrusion. Furthermore, for most construction materials, LCA considers environmental effluents during transport, but no sales section is considered. Because no other construction material's LCA can be considered a substitute for an LCA for CFP and because of a booming use of CFP in China, a whole LCA for CFP is necessary.

This paper conducts a whole LCA ("from cradle to grave") for CFP based on field research in both the sales section and material recycling and compares this LCA with those for 3 other façade materials (marble, glass and aluminum) "from cradle to gate." We did not compare the environment impact of usage and abandonment stages among different materials, due to the scarcity of readymade cases that share the same photothermal environment during the façade's usage.

\section{Goal and scope definition}

\subsection{Goal of the study}

We attempt to conduct an entire life cycle analysis ("from cradle to grave") for CFP and to identify the environmental impact hot spots within the production process. Then, we will compare the environmental impacts of 4 different types of façade life cycles ("from cradle to gate") to determine the façade material with the best environmental profile.

\subsection{Scope of the study}

\subsubsection{System, function of the systems and functional unit}

There are two types of CFP: glazed CFP and plain CFP. The color of the plain CFP is close to the color of pottery clay and thus more popular. Moreover, plain CFP is simple to use because it is the raw material with a small amount of color-matching agent. And according to our interview with factory, plain CFP occupied more than $80 \%$ of the market. Therefore, we chose the plain CFP system as our research object to ensure the representativeness of our study. The functional unit is $1 \mathrm{~m}^{2}$ CFP.

\subsubsection{System boundaries}

Our research covers the entire life cycle process of the CFP system, including the raw material preparation, production, operation and abandonment stages (see Fig. 1 and Appendix A).

\subsubsection{Assumption}

As dust created in the production of CFP is confined to the workshop, and there are no outward emissions, it is excluded from our analysis. Besides, we ignored the impact analysis on those materials weighted less than $0.5 \%$ of $1 \mathrm{~m}^{2}$ CFP's. Meanwhile, we assumed that the service life of the curtain wall will be 50 years, which corresponds to the rental period for state-owned commercial land. For comparative analysis, we used the CFP parameters obtained from our field survey of a typical CFP enterprise. Data on marble plates are derived from large-scale stone enterprises in China that are excellent representatives of the industry. The LCA for marble plates includes an extra polishing process compared with CFP. We conducted the LCA of glass plates on a float glass process that is the basis of a local, state-owned enterprise. Aluminum plate production is based on an electrolytic aluminum process, and the data used are also from a survey of large-scale, state-owned Chinese enterprises. We chose the $3 \mathrm{~mm}$ aluminum plate, $3 \mathrm{~cm}$ marble panel, $3 \mathrm{~cm}$ glass panel and $3 \mathrm{~cm}$ CFP for our research; the thickness is based on that most commonly used in curtain wall construction. Some craft specifications and parameters were obtained from the Chinese indigenous LCA database CLCD 3.0.

\subsubsection{Allocation}

No allocation procedure has been performed because there is no byproduct in the system.

\subsubsection{Impact assessment methodology}

The impact assessment methodology used is a "problem-oriented" assessment, in which, as stated by the ISO ISO14040 (2006), the inventory data are associated with specific environmental 


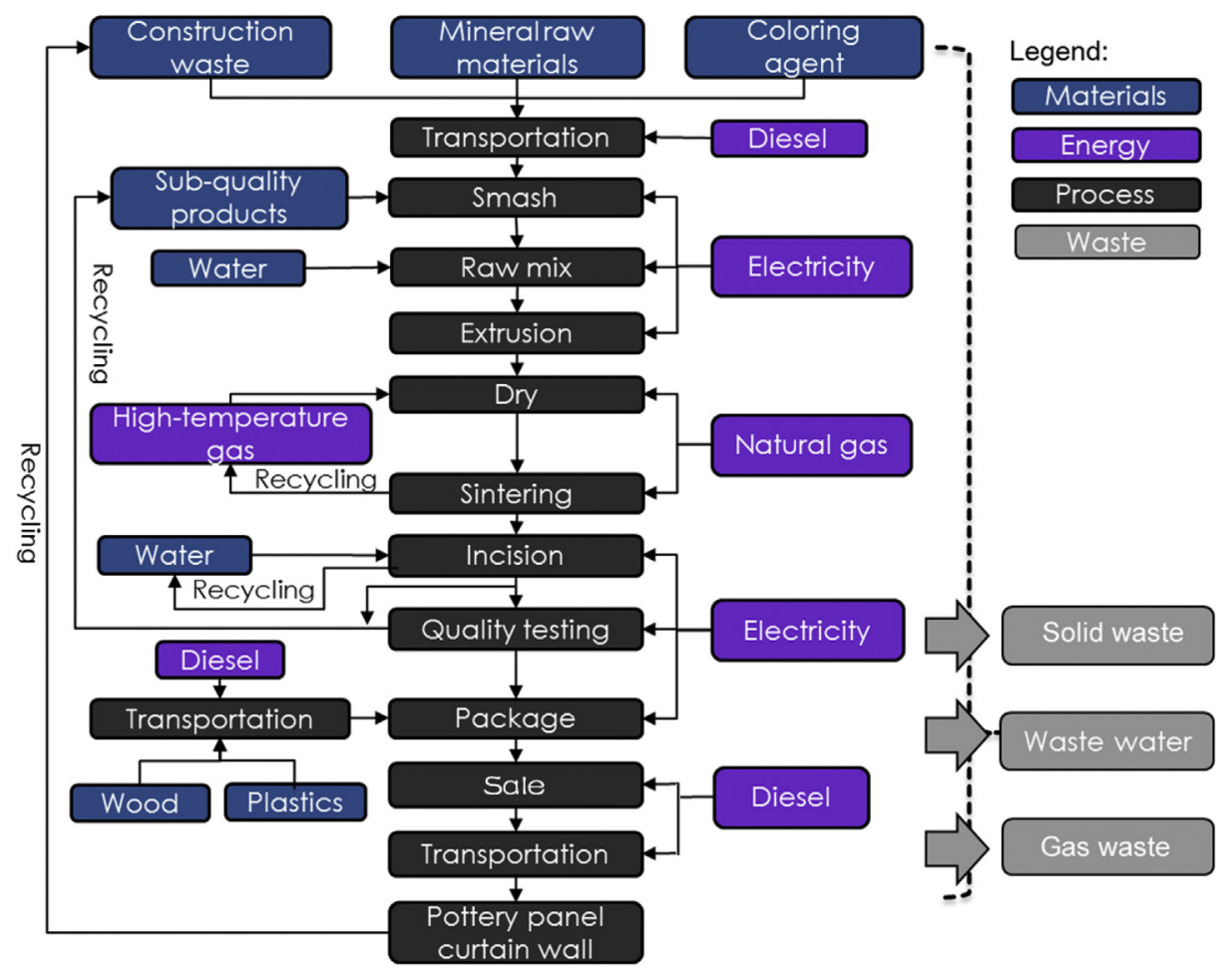

Fig. 1. Process of the CFP life cycle.

impact categories to understand those impacts. The impact assessment method for the present study was CML2001 v.2.05 (Condeixa et al., 2014; Guinée et al., 2002.) and included the following impact categories:

(1) Abiotic Depletion Potential (ADP, unit: kg antimony-eq.): Such substances include raw coal, crude oil, clay, feldspar and iron material. ADP is represented by Fe or antimony equivalent.

(2) Photochemical Ozone Creation Potential (POCP, kg ethyleneeq.): Photochemical smog is a regional environmental pollution problem and will cause human respiratory disease and harm the growth of crops.

(3) Global Warming Potential (GWP, $\mathrm{kg} \mathrm{CO}_{2}$-eq.): Some compounds could absorb long wave radiation which is supposed to go back to the atmosphere, leading to the global temperature increase.

(4) Ozone Depletion Potential (ODP, kg CFC-11-eq.): Halocarbon generated by industrial production has great damage effect on ozone $\left(\mathrm{O}_{3}\right)$ and the ultraviolet ray would directly reach the ground without the resistance of $\mathrm{O}_{3}$ which harms human health and the earth's ecosystem.

(5) Eutrophication Potential (EP, $\mathrm{kg} \mathrm{PO}_{4}^{3-}$-eq.): Excessive content of nitrogen $(\mathrm{N})$ and phosphorus $(\mathrm{P})$ and other nutrients will make the aquatic organisms, especially algae, blooms resulting in the decrease of dissolved oxygen in water.

(6) Acidification Potential (AP, $\mathrm{kg} \mathrm{SO}$-eq.): Acid substances could cause the acidification of environment where they discharged. Such substances include $\mathrm{SO}_{2}, \mathrm{SO}_{3} / \mathrm{SO}_{\mathrm{X}}, \mathrm{NH}_{3}, \mathrm{NO}_{\mathrm{X}}$, $\mathrm{HCL}$ and $\mathrm{H}_{2} \mathrm{~S}$.

(7) Human Toxicity Potential (HTP, kg 1, 4-DCB-eq.): Toxic substances entered human body through respiratory tract, enteron and skin contact causing human body function disorder. Such substances include $\mathrm{SO}_{2}, \mathrm{NO}_{\mathrm{x}}, \mathrm{CO}, \mathrm{Pb}, \mathrm{Cu}, \mathrm{Cd}$, xylene, benzene etc.

\section{Inventory analysis}

\subsection{Raw material preparation stage}

(1) Kaolin crushing: 3\% Ore loss; Ore transportation: $206 \mathrm{~km} * \mathrm{~kg}$; distance $200 \mathrm{~km}$, power consumption $0.0089 \mathrm{kwh} / \mathrm{kg}$.

(2) Aggregate crushing: Construction waste transportation: $210 \mathrm{~km}^{*} \mathrm{~kg}$, distance $200 \mathrm{~km}$; power consumption 0.0077 $\mathrm{kwh} / \mathrm{kg}$; $85 \%$ construction waste, $20 \%$ leftover material, $5 \%$ construction waste loss in transportation.

(3) Aggregate raw material (construction waste): $40 \%$ waste CFP; $60 \%$ construction waste.

(4) Aggregate raw material (leftover material): reuse rate $100 \%$.

(5) Additive preparation: $80 \%$ fluxing agent; $8 \%$ color matching agent; $12 \%$ embryonic body enhancer.

\subsection{Product production stage}

(1) Raw materials mixing:aggregate $31 \%$, additive $26 \%$, kaolin $46 \%, 1 \%$ loss rate for every material in this process; power consumption $0.007 \mathrm{kwh} / \mathrm{kg}$, kaolin material transportation $1.38 \mathrm{~kg}^{*} \mathrm{~km}$, distance $3 \mathrm{~km}$, aggregate transportation $0.93 \mathrm{~km}^{*} \mathrm{~kg}$, distance $3 \mathrm{~km}$, additive transportation $130 \mathrm{~km} * \mathrm{~kg}$, distance $500 \mathrm{~km}$.

(2) Watering: power consumption $0.00833 \mathrm{kwh} / \mathrm{kg}, 87 \%$ mixed material; $15 \%$ water; $1 \%$ loss rate.

(3) Extrusion molding: $43.06 \mathrm{~kg}$ mud produces $1 \mathrm{~m}^{2}$ wet plate with a $0.5 \mathrm{~kg}$ loss, power consumption $0.9219 \mathrm{kwh} / \mathrm{m}^{2}$.

(4) Heat drying: $1.053 \mathrm{~m}^{2}$ wet plate produces $1 \mathrm{~m}^{2}$ dry plate, power consumption $0.4211 \mathrm{kwh} / \mathrm{m}^{2}, 0.579 \mathrm{~m}^{3}$ of natural gas consumption and reused waste heat equals heat generated by $0.05 \mathrm{~m}^{3}$ of natural gas.

(5) Kiln sintering: $1.218 \mathrm{~m}^{2}$ dry plates produce $1 \mathrm{~m}^{2}$ CFP, power consumption $0.9745 \mathrm{kwh} / \mathrm{m}^{2}, 6.107 \mathrm{~m}^{3}$ of natural gas 
consumption and reused waste heat equals heat generated by $0.1 \mathrm{~m}^{3}$ of natural gas.

(6) Edge cutting: $1.08 \mathrm{~m}^{2}$ of CFP produces $1 \mathrm{~m}^{2}$ finished product, power consumption $0.2667 \mathrm{kwh} / \mathrm{m}^{2}, 0.08 \mathrm{~m}^{2}$ scrap is approximately $3.36 \mathrm{~kg}$.

(7) Packing: 1 wooden case contains $20 \mathrm{~m}^{2}$ CFP; $0.05 \mathrm{~kg}$ foam board.

\subsection{Operation and disposal stage}

(1) Sales: Office electric consumption of $1 \mathrm{~m}^{2} \mathrm{CFP} 0.1333 \mathrm{kwh} /$ $\mathrm{m}^{2}$, office traffic for the sale of $1 \mathrm{~m}^{2} \mathrm{CFP} 75 \mathrm{~kg}^{*} \mathrm{~km}$.

(2) CFP installation: Transport consumption per $\mathrm{m}^{2}$ CFP is $46,200 \mathrm{~kg}^{*} \mathrm{~km}$ (Beijing as a destination), CFP loss rate in transportation $1 \%$, aluminum alloy auxiliary materials $1.62 \mathrm{~kg}$, steel keel auxiliary material $3.68 \mathrm{~kg}$.

(3) Curtain wall maintenance in operation: service life 50 years, $1 \mathrm{~L}$ water consumption per $\mathrm{m}^{2} \mathrm{CFP}$ at the frequency of one cleaning per year.

(4) Wasted curtain wall disposal: For a $1 \mathrm{~m}^{2}$ CFP curtain wall demolition, $32 \mathrm{~kg}$ wasted CFP are dumped and $10 \mathrm{~kg}$ are reused, transportation to landfill $6000 \mathrm{~kg}^{*} \mathrm{~km}$, distance 200 km (Fig. 2).

\section{Environmental impact assessment}

\subsection{Environmental impact contributing factor analysis (Table 1)}

\subsection{Environmental impact and contribution analysis by process and stage}

\subsubsection{Processes in the raw material preparation stage}

The raw material preparation stage mainly includes kaolin and aggregate crushing and additive preparation. Kaolin crushing includes power consumption in kaolin ore mining, transport, and crushing processes; the preparation of additives, including cosolvent and toner producing processes; and aggregate crushing, which includes electricity consumption in construction waste and scrap crushing and transportation of the waste CFP. The characteristic environmental impact values of the detailed processes in the raw materials preparation stage are shown in Table 2 and Fig. 3.

\subsubsection{Production stage of CFP}

The production stage includes 7 processes: raw materials mixing, puddling, extrusion molding, heat drying, kiln sintering, edge cutting and product packing. The characteristic environmental impact values of the detailed processes are listed in Table 3 and Fig. 4.

\subsubsection{Usage and abandonment stage of CFP}

The usage and abandonment stage of CFP includes sales, installation, and maintenance during the use process, demolition and disposal. In our study, approximately $10 \mathrm{~kg}$ of $1 \mathrm{~m}^{2}$ CFP is transported to the landfill, and the remaining is reused by the factory. The characteristic environmental impact values at each stage are shown in Table 4 and Fig. 5.

4.2.4. The environmental impact comparison for the entire process (Fig. 6)

\section{A comparative analysis of the curtain wall products}

\subsection{Description of the product comparison}

Our research also compared CFP with the other three typical curtain wall products: marble, glass and aluminum plate. Considering the determining role of product specifications on function, we chose $30 \mathrm{~mm}$ CFP, $30 \mathrm{~mm}$ marble, $15 \mathrm{~mm}$ glass, and $3 \mathrm{~mm}$ aluminum plates for comparison. The functional unit is $1 \mathrm{~m}^{2}$, based on the same principle function and daily usage. In accordance with CFP, we compared the above 7 environmental impacts of the four products. All the data for the other three typical curtain wall products were obtained by literature research which were cited in the 4th and 5th paragraphs in Section 1. And the processing diagrams of them could be found in those citations too.

\subsection{Comparative analysis result}

(1) ADP index sequence of four types of construction materials: aluminum plate $>$ marble $>$ CFP $>$ glass. The CFP ADP index value is far lower than the aluminum plate and is 0.627 times, 1.04 times and 0.0774 times the value of the marble, glass and aluminum plates, respectively.

(2) POCP index sequence: aluminum plate $>$ marble $>$ glass $>\mathrm{CF}$ $P$. The POCP index of CFP has the minimum POCP environmental impact, far less than aluminum, and is 0.234 times, 0.262 times and 0.14 times the value of the marble, glass and aluminum plates, respectively.

(3) GWP index sequence: aluminum plate $>$ marble $>$ glass $>$ CFP. CFP generated the least environmental impact in terms of global warming, far less than aluminum and is 0.436 times,

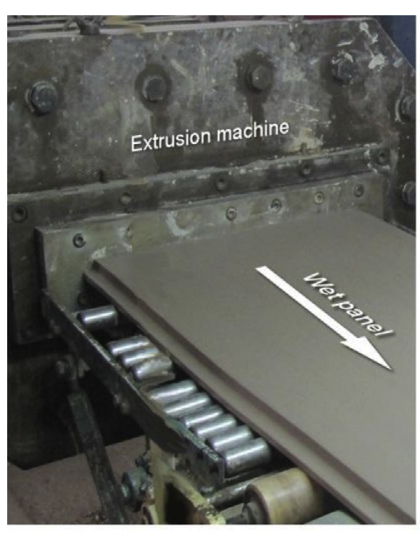

Extrusion process

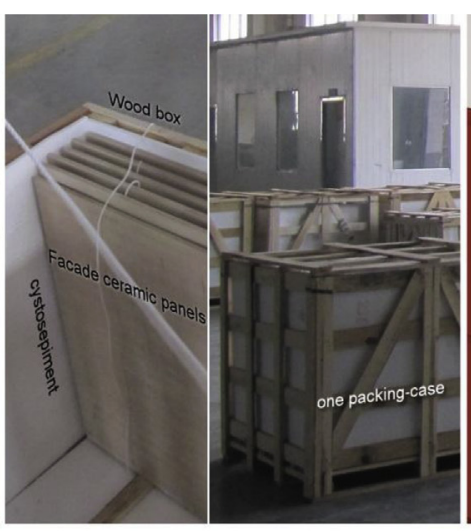

Package process

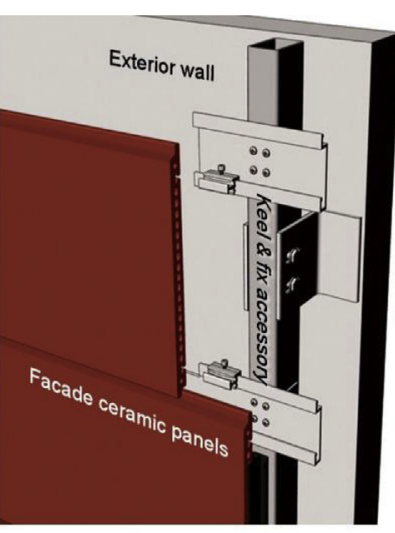

Installation process

Fig. 2. Parts of the process of the CFP life cycle. 
Table 1

Characteristic values of the environmental impact indicators in the CFP life cycle analysis.

\begin{tabular}{|c|c|c|c|c|c|c|c|}
\hline & ADP & $\mathrm{AP}$ & EP & GWP & ODP & POCP & HTP \\
\hline Cradle to Gate & $1.653 \mathrm{E}-4$ & $1.346 \mathrm{E}-1$ & $2.289 \mathrm{E}-2$ & $3.106 \mathrm{E}+1$ & $9.370 \mathrm{E}-7$ & $4.151 \mathrm{E}-3$ & $3.859 \mathrm{E}+1$ \\
\hline Cradle to Cradle & $5.440 \mathrm{E}-4$ & $5.225 \mathrm{E}-1$ & $1.167 \mathrm{E}-1$ & $7.066 \mathrm{E}+1$ & $2.830 \mathrm{E}-6$ & $1.916 \mathrm{E}-2$ & $1.918 \mathrm{E}+2$ \\
\hline
\end{tabular}

Table 2

The characteristic environmental impact values of the processes in the raw materials preparation stage.

\begin{tabular}{|c|c|c|c|c|c|c|c|}
\hline & ADP & $\mathrm{AP}$ & EP & GWP & ODP & POCP & HTP \\
\hline Kaolin crushing & $3.82 \mathrm{E}-05$ & 4.83E-02 & $1.05 \mathrm{E}-02$ & $6.34 \mathrm{E}+00$ & $5.36 \mathrm{E}-07$ & $1.71 \mathrm{E}-03$ & $2.91 \mathrm{E}+01$ \\
\hline Additive preparation & $6.80 \mathrm{E}-06$ & $4.02 \mathrm{E}-03$ & $7.36 \mathrm{E}-04$ & $5.39 \mathrm{E}-01$ & $3.36 \mathrm{E}-08$ & $1.34 \mathrm{E}-04$ & $2.45 \mathrm{E}+00$ \\
\hline Aggregate crushing & $2.72 \mathrm{E}-06$ & $1.47 \mathrm{E}-02$ & 2.57E-03 & $8.26 \mathrm{E}-01$ & $6.00 \mathrm{E}-08$ & $1.79 \mathrm{E}-04$ & 7.13E-01 \\
\hline
\end{tabular}
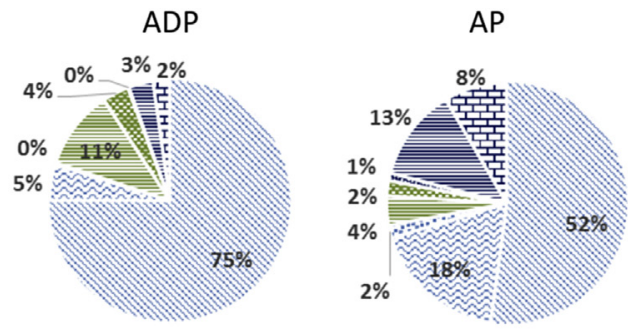

ODP
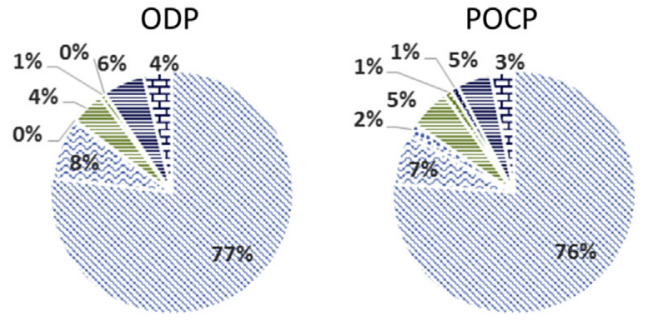
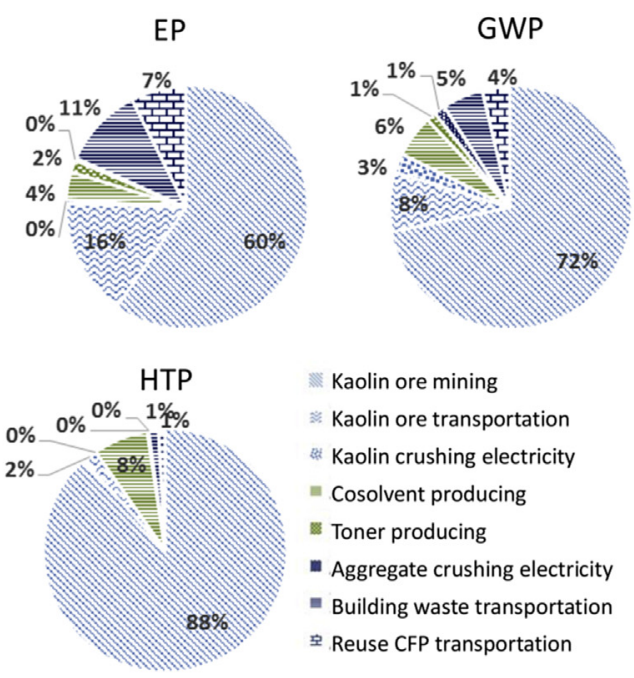

Fig. 3. The environmental impact proportions of the processes in the raw materials preparation stage.

0.773 times and 0.159 times the value of the marble, glass and aluminum plates, respectively.

(4) ODP index sequence: marble $>$ glass $>$ aluminum plate $>$ CFP. The ODP of CFP is far less than that of the marble and is 0.208 times, 0.382 times and 0.571 times the value of the marble, glass and aluminum plates, respectively.

(5) EP index sequence: marble $>$ aluminum plate $>$ glass $>$ CFP. The EP of CFP is far less than the marble. The EP of CFP is far smaller than the marble and is 0.192 times, 0.388 times and 0.388 times the value of the marble, glass and aluminum plates, respectively.

(6) AP index sequence: aluminum plate $>$ glass $>$ marble $>$ CFP. The AP of CFP is far less than the aluminum plate and is 0.271 times, 0.214 times and 0.140 times the value of the marble, glass and aluminum plates.

(7) HTP index sequence: marble $>$ CFP $>$ glass $>$ aluminum plate. The HTP of CFP is far less than marble and is 0.132 times, 1.30 times and 1.69 times the value of the marble, glass and aluminum plates, respectively (Fig. 7 and Table 5).

\section{Discussion \& Conclusion}

\subsection{Limitations in a comparative study of different products}

Current curtain wall products are produced with a variety of upgrades in function and materials, such as surface glazing to improve the appearance of CFP; dustproof, self-cleaning coatings of stone and glass; and aluminous model boards and foam plates that are press-fit to preserve heat. Thus, we weighed the comparativeness and representativeness of the products for our study, and we chose the original plate without surface treatment for the LCA comparison analysis. Generally, the comparison results are persuasive, but the significance in reference to specific curtain walls is weak.

\subsection{The LCA of CFP and its analysis}

The entire life cycle assessment (from cradle to grave) of a $1 \mathrm{~m}^{2}$ typical CFP showed that the kaolin ore mining process in the raw materials preparation stage made the dominant contribution in all 7

Table 3

The characteristic environmental impact values of the processes in the production stage of CFP.

\begin{tabular}{|c|c|c|c|c|c|c|c|}
\hline Processes & ADP & $\mathrm{AP}$ & EP & GWP & ODP & POCP & HTP \\
\hline Raw materials mixing & $4.88 \mathrm{E}-06$ & $2.68 \mathrm{E}-02$ & $4.58 \mathrm{E}-03$ & $1.60 \mathrm{E}+00$ & $1.06 \mathrm{E}-07$ & 3.39E-04 & $1.26 \mathrm{E}+00$ \\
\hline Puddling & $2.96 \mathrm{E}-07$ & $2.66 \mathrm{E}-03$ & $1.65 \mathrm{E}-04$ & $4.68 \mathrm{E}-01$ & $1.21 \mathrm{E}-09$ & 8.19E-05 & $9.80 \mathrm{E}-03$ \\
\hline Extrusion molding & $7.60 \mathrm{E}-07$ & $6.84 \mathrm{E}-03$ & $4.25 \mathrm{E}-04$ & $1.20 \mathrm{E}+00$ & 3.11E-09 & 2.10E-04 & $2.52 \mathrm{E}-02$ \\
\hline Heat drying & $3.08 \mathrm{E}-06$ & $3.56 \mathrm{E}-03$ & $2.28 \mathrm{E}-04$ & $8.08 \mathrm{E}-01$ & 5.22E-09 & $1.11 \mathrm{E}-04$ & $7.72 \mathrm{E}-02$ \\
\hline Kiln sintering & 2.67E-05 & $1.12 \mathrm{E}-02$ & $7.66 \mathrm{E}-04$ & $2.75 \mathrm{E}+00$ & 3.92E-08 & 3.57E-04 & $6.50 \mathrm{E}-01$ \\
\hline Edge cutting & $1.59 \mathrm{E}-07$ & $1.43 \mathrm{E}-03$ & 8.87E-05 & $2.51 \mathrm{E}-01$ & $6.50 \mathrm{E}-10$ & 4.39E-05 & $5.26 \mathrm{E}-03$ \\
\hline Packing & $5.18 \mathrm{E}-05$ & 7.73E-03 & $2.33 \mathrm{E}-03$ & $1.24 \mathrm{E}+00$ & $1.07 \mathrm{E}-07$ & 6.67E-04 & $3.55 \mathrm{E}+00$ \\
\hline
\end{tabular}




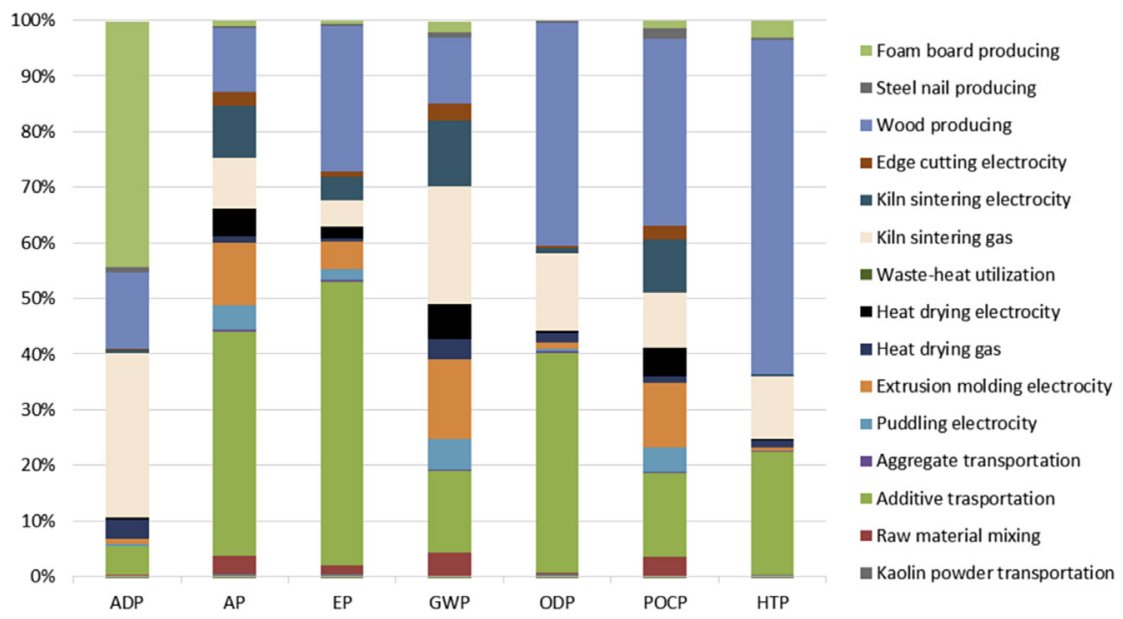

Fig. 4. The environmental impact proportions of processes in the production stage.

Table 4

The characteristic environmental impact values by process in the usage and abandonment stage of CFP.

\begin{tabular}{|c|c|c|c|c|c|c|c|}
\hline Processes & ADP & AP & $\mathrm{EP}$ & GWP & ODP & РOCP & HTP \\
\hline Sales & $1.88 \mathrm{E}-07$ & $9.09 \mathrm{E}-04$ & $7.68 \mathrm{E}-05$ & $1.49 \mathrm{E}-01$ & $3.04 \mathrm{E}-09$ & $1.08 \mathrm{E}-04$ & $3.50 \mathrm{E}-02$ \\
\hline Installation & $3.55 \mathrm{E}-04$ & 3.00E-01 & 7.79E-02 & $3.47 \mathrm{E}+01$ & $1.50 \mathrm{E}-06$ & $1.39 \mathrm{E}-02$ & $1.47 \mathrm{E}+02$ \\
\hline Maintenance & $0.00 \mathrm{E}+00$ & $0.00 \mathrm{E}+00$ & $0.00 \mathrm{E}+00$ & $0.00 \mathrm{E}+00$ & $0.00 \mathrm{E}+00$ & $0.00 \mathrm{E}+00$ & $0.00 \mathrm{E}+00$ \\
\hline Demolition & $6.55 \mathrm{E}-06$ & $7.14 \mathrm{E}-03$ & $1.30 \mathrm{E}-03$ & $5.01 \mathrm{E}-01$ & $4.68 \mathrm{E}-08$ & $1.34 \mathrm{E}-04$ & $1.26 \mathrm{E}+00$ \\
\hline Disposal & $1.54 \mathrm{E}-05$ & 8.00E-02 & $1.43 \mathrm{E}-02$ & $4.08 \mathrm{E}+00$ & $3.41 \mathrm{E}-07$ & $9.15 \mathrm{E}-04$ & $4.18 \mathrm{E}+00$ \\
\hline
\end{tabular}

characteristic environmental impacts. The gas generated during the heat drying had the greatest environmental influence in terms of ADP and GWP. The transportation of additives contributed the most to the AP and EP environmental influence. The wood production process in the packing stage and the gas from the heat drying made the largest contribution to the ODP. In addition, the wood production process in the packing stage was also the largest contributor to POCP and HTP; in the operation and abandonment stage, the steel keel in the CFP installation contributed the most to ADP. The manufacture of aluminum material in the CFP installation had the greatest effect on the other 6 environmental impacts. Besides, according to the analysis on sale process (Table 4), the environmental impact of sale section was little, and the exclusion of this section in future research could not cause significant influence on the result.

Comparing all transportation processes, transportation of the finished CFP had the greatest influence on the environment. A comparison of all of the stages of the power consumption process showed that the extrusion stage had the greatest influence on the environment, followed by the kiln sintering stage. A comparison of the natural gas consumption across all processes showed that the kiln sintering stage had the greatest influence. An analysis of the entire life cycle process showed that steel keel in the CFP installation had the greatest effect in the production of ADP. The aluminum hook accessory in the CFP installation had the largest effect on the other 6 environmental impacts.

\subsection{Suggestions for reducing the environmental impact of CFP production based on this life cycle analysis}

The production process should further increase natural gas efficiency. On the one hand, the life cycle analysis showed that natural gas is the largest contributor to ODP, ADP, and GWP; on the other hand, there is no thermal insulation measurement for the waste heat utilization pipeline, which can also cause unnecessary heat waste. In the CFP operation stage, the design of the CFP joint structure should be optimized to reduce the use of the aluminum hook accessory, thus reducing the environmental impact. Finally, the optimum balance point of the discarded CFP recycling can be calculated through an overall consideration of the transport distance, economic interests and environmental interests, which will be discussed in other related studies.

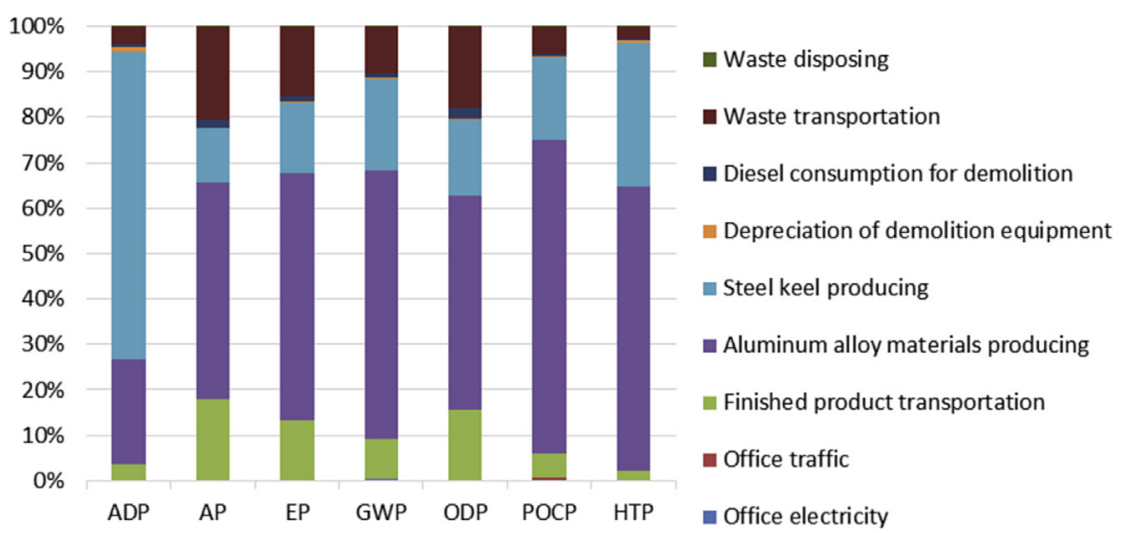

Fig. 5. The environmental impact proportions by processes in the usage and abandonment stage. 


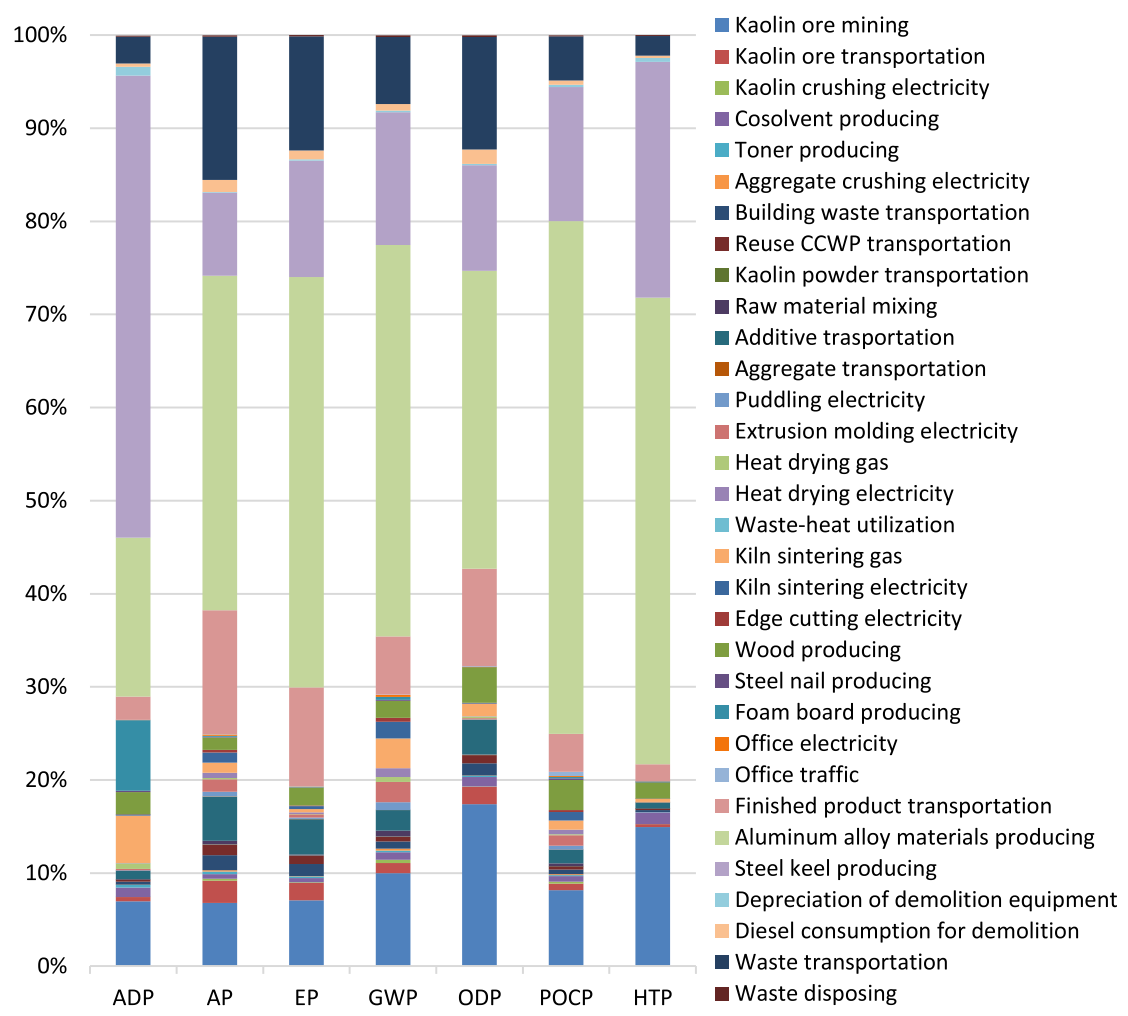

Fig. 6. The proportions of the environmental impacts of all processes and stages.

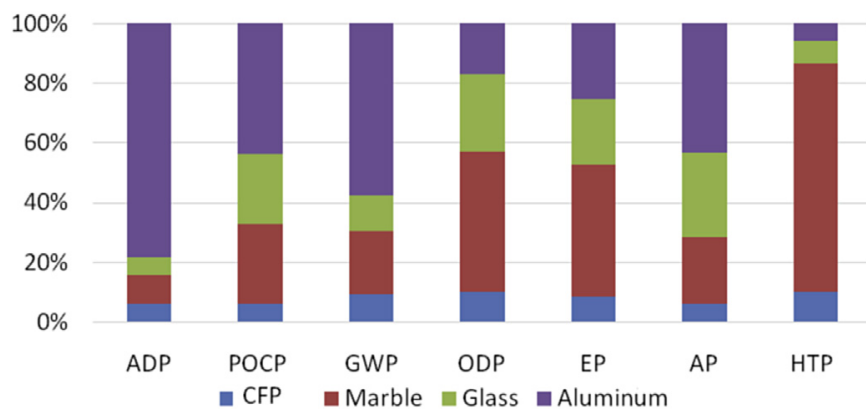

Fig. 7. The proportion among the 4 different building materials for each of the characteristic values.

\subsection{The selection of façade material from an environmental impact view}

In the production of façade materials, the performance of marble was worse than the other three materials for the environmental impact indicators HTP, EP and ODP and was the second-worst for ADP, POCP and GWP. These environmental impacts were caused mainly by quarrying and cutting. Although marble is believed to have some disadvantages as a façade material because of its heavy weight and poor plasticity, building designers usually think of

Table 5

The characteristic values of the environmental impact of four construction materials.

\begin{tabular}{lllll}
\hline Index & CFP $(30 \mathrm{~mm})$ & Marble $(30 \mathrm{~mm})$ & Glass $(15 \mathrm{~mm})$ & Aluminum $(3 \mathrm{~mm})$ \\
\hline ADP & $1.65 \mathrm{E}-04$ & $2.63 \mathrm{E}-04$ & $1.59 \mathrm{E}-04$ & $2.14 \mathrm{E}-03$ \\
POCP & $4.15 \mathrm{E}-03$ & $1.77 \mathrm{E}-02$ & $1.59 \mathrm{E}-02$ & $2.96 \mathrm{E}-02$ \\
GWP & $3.11 \mathrm{E}+01$ & $7.12 \mathrm{E}+01$ & $4.02 \mathrm{E}+01$ & $1.95 \mathrm{E}+02$ \\
ODP & $9.37 \mathrm{E}-07$ & $4.50 \mathrm{E}-06$ & $2.45 \mathrm{E}-06$ & $1.64 \mathrm{E}-06$ \\
EP & $2.29 \mathrm{E}-02$ & $1.19 \mathrm{E}-01$ & $5.90 \mathrm{E}-02$ & $6.94 \mathrm{E}-02$ \\
AP & $1.35 \mathrm{E}-01$ & $4.97 \mathrm{E}-01$ & $6.28 \mathrm{E}-01$ & $9.62 \mathrm{E}-01$ \\
HTP & $3.86 \mathrm{E}+01$ & $2.92 \mathrm{E}+02$ & $2.96 \mathrm{E}+01$ & $2.29 \mathrm{E}+01$ \\
\hline
\end{tabular}

natural marble as a symbol of upscale building material, especially when large pieces are used for complete façades. We seriously suggest that natural marble should be used as little as possible, given its bad performance on environmental impact assessments.

Aluminum panels were no better than marble, as they performed the worst on ADP, POCP, GWP and AP, and second-worst on EP. These environmental impacts were caused mainly by the mining, forging and pressing procedures for aluminum. However, aluminum panels are superior to other material in many ways, as they are light weight, have good plasticity, are convenient for surface coloring and are compatible with other thermal insulation materials. With this understanding, a selection of aluminum façade panels should be comprehensively considered, given aluminum's anticipated environmental impact performance during the usage period.

Glass performed better than marble and aluminum panels, generally, but was the second-worst for ODP and AP. As glass is a recycled resource and has high luminousness, it has been widely used on the façades of high-rise buildings. Although there is less environmental impact during its production, light pollution cannot be ignored during its usage period. Both the urban heat island effect and traffic accidents caused by dazzling are directly related to light pollution.

CFP performed the best compared with the other 3 materials, but was the second-worst on HTP. However, its environmental impact on HTP was $13.2 \%$ of the marble, $130 \%$ of the glass and $169 \%$ of the aluminum panels, respectively. In this view, the environmental impacts on HTP by the production of CFP, glass and aluminum, separately, were very close. The main reason for the HTP impact was the use of cystosepiment and wood in the packaging stage. Other than that, CFP has the best performance in the production period, is a recycled resource, and could be made with construction waste. Furthermore, the extrusion process yields a material with plasticity and a hollow structure that is good for thermal insulation. Additionally, the surface texture of CFP makes it easy to paint in an imitation of marble or metal. Based on the above analysis, we recommend CFP as an environmentally friendly material. 


\section{Acknowledgments}

The authors thank Bin Chen for their valuable suggestions. Thanks also to Zhiping Xia for his help on the data collection. This research was supported by the National Natural Science Foundation of China (No. 71033005).

\section{Appendix A}

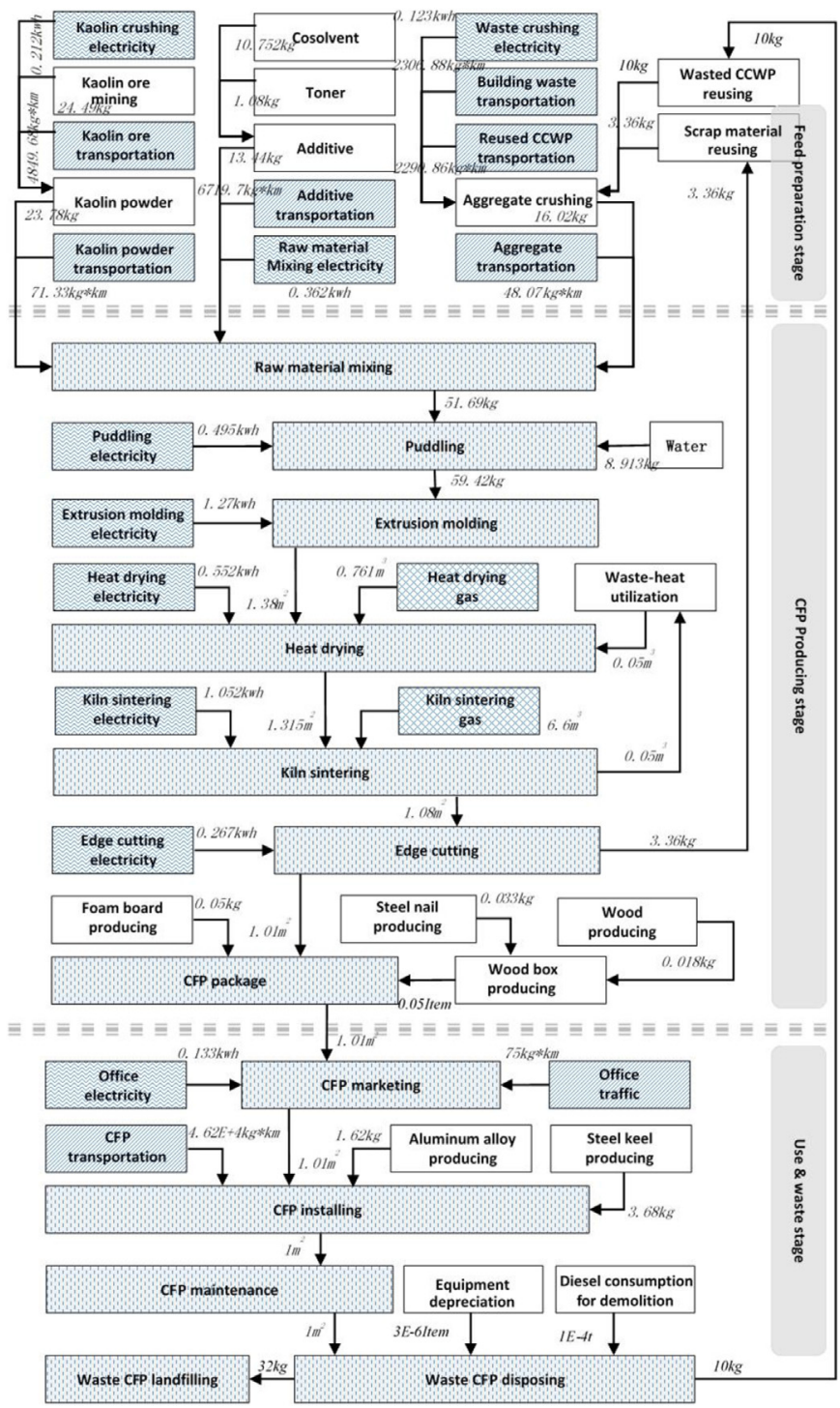

Fig. A. Process of the CFP life cycle with detailed data.

\section{References}

Agrawal, K.K., Jain, S., Jain, A.K., Dahiya, S., 2014. A life cycle environmental impact assessment of natural gas combined cycle thermal power plant in Andhra Pradesh, India. Environ. Dev. 11, 162-174.

Cabeza, L.F., Rincón, L., Vilariño, V., Pérez, G., Castell, A., 2014. Life cycle assessment (LCA) and life cycle energy analysis (LCEA) of buildings and the building sector: a review. Renew. Sustain. Energy Rev. 29, 394-416.

Citherlet, S., Di Guglielmo, F., Gay, J.-B., 2000. Window and advanced glazing systems life cycle assessment. Energy Build. 32, 225-234.

Condeixa, K., Haddad, A., Boer, D., 2014. Life Cycle Impact Assessment of masonry system as inner walls: a case study in Brazil. Constr. Build. Mater. 70, $141-147$.

Edis, E., Flores-Colen, I., de Brito, J., 2014. Passive thermographic detection of moisture problems in façades with adhered ceramic cladding. Constr. Build. Mater. 51, 187-197.

Gazi, A., Skevis, G., Founti, M.A., 2012. Energy efficiency and environmental assessment of a typical marble quarry and processing plant. J. Clean. Prod. 32. $10-21$.

Gu, L., Lin, B., Zhu, Y., Gu, D., Huang, M., Gai, J., 2008. Integrated Assessment Method for Building Life Cycle Environmental and Economic Performance, Building Simulation. Springer, pp. 169-177.

Guinée, J., Gorree, M., Heijungs, R., Huppes, G., Kleijn, R., de Koning, A., Wegener, Sleeswijk, A., Suh, S., Udo de Haes, H.A., De Bruijn, J.A., Van Duin, R., Huijbregts, M.A.J., 2002. Handbook on Life Cycle Assessment. Operational Guide to the ISO Standards. Kluwer Academic Publishers, Dordrecht, the Netherlands.

Huovila, P., 2007. Buildings and Climate Change: Status, Challenges, and Opportunities. UNEP/Earthprint.

Incropera, F.P., 2011. Introduction to Heat Transfer. John Wiley \& Sons.

ISO14040, 2006. Environmental Management - Life Cycle Assessment - Principles and Framework.

Kim, K.-H., 2011. A comparative life cycle assessment of a transparent composite façade system and a glass curtain wall system. Energy Build. 43, 3436-3445.

Manfredi, M., Vignali, G., 2014. Life cycle assessment of a packaged tomato puree: a comparison of environmental impacts produced by different life cycle phases. J. Clean. Prod. 73, 275-284.

Monteiro, H., Freire, F., 2012. Life-cycle assessment of a house with alternative exterior walls: comparison of three impact assessment methods. Energy Build. 47, 572-583.

Nicoletti, G.M., Notarnicola, B., Tassielli, G., 2002. Comparative Life Cycle Assessment of flooring materials: ceramic versus marble tiles. J. Clean. Prod. 10, 283-296.

Ottelé, M., Perini, K., Fraaij, A., Haas, E., Raiteri, R., 2011. Comparative life cycle analysis for green façades and living wall systems. Energy Build. 43, 3419-3429.

Radhi, H., Sharples, S., 2013. Global warming implications of facade parameters: a life cycle assessment of residential buildings in Bahrain. Environ. Impact Assess. Rev. 38, 99-108.

Shameri, M., Alghoul, M., Sopian, K., Zain, M.F.M., Elayeb, O., 2011. Perspectives of double skin façade systems in buildings and energy saving. Renew. Sustain. Energy Rev. 15, 1468-1475.

Taborianski, V.M., Prado, R.T.A., 2012. Methodology of $\mathrm{CO}_{2}$ emission evaluation in the life cycle of office building façades. Environ. Impact Assess. Rev. 33, 41-47.

Tikul, N., 2013. Environmental performance of marble tile life cycle. Appl. Environ. Res. 34.

Traverso, M., Rizzo, G., Finkbeiner, M., 2010. Environmental performance of building materials: life cycle assessment of a typical Sicilian marble. Int. J. Life Cycle Assess. 15, 104-114.

Weir, G., Muneer, T., 1998. Energy and environmental impact analysis of doubleglazed windows. Energy Convers. Manag. 39, 243-256. 